\title{
Reducing sediment concentration and soil loss using organic and inorganic amendments at plot scale
}

\author{
S. H. R. Sadeghi ${ }^{1}$, L. Gholami ${ }^{1, *}$, M. Homaee ${ }^{2}$, and A. Khaledi Darvishan ${ }^{1}$ \\ ${ }^{1}$ Department of Watershed Management Engineering, Faculty of Natural Resources, \\ Tarbiat Modares University, Noor 46417-76489, Iran \\ ${ }^{2}$ Department of Soil Sciences, Faculty of Agriculture, Tarbiat Modares University, Tehran, Iran \\ *now at: Department of Rangeland and Watershed Management, Faculty of Natural Resources, \\ Sari Agricultural Sciences and Natural Resources University, Sari, Iran \\ Correspondence to: S. H. R. Sadeghi (sadeghi@modares.ac.ir)
}

Received: 10 September 2014 - Published in Solid Earth Discuss.: 13 January 2015

Revised: 4 April 2015 - Accepted: 9 April 2015 - Published: 29 April 2015

\begin{abstract}
Various organic and inorganic mulches are used for soil conservation purposes, the effectiveness of which on soil characteristics has not been comprehensively considered from different aspects. The present study surveys the efficiency of straw mulch, manure and TA-200 polyacrylamide with respective rates of 500,300 and $50 \mathrm{~g} \mathrm{~m}^{-2}$ in changing sediment concentration and soil loss. The experiments were conducted for sandy-loam soil taken from a summer rangeland, the Alborz Mountains, northern Iran. The experiments were performed under laboratory conditions with simulated rainfall intensities of $30,50,70$ and $90 \mathrm{~mm} \mathrm{~h}^{-1}$ and a slope of $30 \%$. The results showed that the straw mulch decreased soil erosion at rate of $45.60 \%$ compared to the control plots and performed better than manure $(8.98 \%$ reduction) and PAM ( $4.74 \%$ reduction). The results showed that the maximum reduction in sediment concentration and soil loss for all soil amendments occurred at the rainfall intensity of $90 \mathrm{~mm} \mathrm{~h}^{-1}$ with the rates of 58.69 and $63.24 \%$ for straw mulch, 14.65 and $13.14 \%$ for manure and 20.15 and $23.44 \%$ for TA-200.
\end{abstract}

\section{Introduction}

Topsoil erosion is a global problem that causes environmental pollution of waterways and loss of soil fertility (Cerdà et al., 2009a and b, 2013). Runoff transports organic materials and heavy metals and pollutes the water bodies. Erosion is therefore known as a serious problem in the world (Wolancho, 2010), especially in developing countries, because of land-use changes at large scales without considering land capabilities. Many methods of soil conservation with different performances and mechanisms have been developed in recent decades. For example, various natural, organic and inorganic mulches, viz. crop residues, leaf litter, woodchips, bark chips, biological geotextiles, gravel and crushed stones (Gilley et al., 1986; Cerdà, 2001; Smets et al., 2008; Xu et al., 2012; Gabarrón-Galeote et al., 2013; Mandal and Sharda, 2013; Zhao et al., 2013; Moreno-Ramón et al., 2014), have been applied for soil conservation. Mulches can increase the infiltration capacity of a soil and strongly control soil erosion (Morgan, 1986), runoff and sediment yield (Poesen and Lavee, 1991; Cerdà, 1998). When the vegetation cover cannot be established, organic and inorganic mulches can be used to protect the soil surface against the erosive forces of rain and runoff (Smets et al., 2008). Previous studies have been conducted about application of soil amendments to improve soil structure (e.g., Karami et al., 2012), change soil and water behavior (e.g., Huang et al., 2014) and reduce postfire runoff and soil erosion in recent years (e.g., Prats et al., 2014). Straw mulch as an organic amendment reduces soil erosion but also recovers the main soil properties lost due to the agriculture (García-Orenes et al., 2010). Mannering and Meye (1963) and Adams (1966) showed that the straw mulch could reduce soil erosion in plot scale. Adekalu et al. (2007) showed that the sediment yield decreased with the amount of mulch used and increased with slope. Groen and Woods (2008) investigated the role of straw mulch in reducing post-wildfire erosion and showed that the straw mulch ap- 
plication was highly effective in reducing erosion in the first year after fire. Jiang et al. (2011) found that the wheat straw reduced soil erosion by $95 \%$ compared to bare soil. Fernández et al. (2012) stated that the conserved treatments (seeding and mulching + seeding) did not significantly increase soil cover or affect runoff, but soil losses were low in all cases. Li et al. (2011) found that the grass mulch significantly reduced sediment yield at large plot scale. Liu et al. (2012) successfully reported the decreasing effect of rice straw mulch at plot scale for a period of 2 years in the Xiaofuling watershed in China. Gholami et al. (2013) studied straw mulching effect on sediment yield from eroded plots and showed that the straw mulch had a significant effect in changing soil erosion characteristics at a confidence level of $99 \%$. Shi et al. (2013) verified the positive effects of mulch cover on reduction of soil loss. Fernandez and Vega (2014) investigated the effects of straw mulch on erosion control after wildfire and showed that the straw mulch could decrease soil erosion. More recently, the scale effects of two plot sizes of 6 and $0.25 \mathrm{~m}^{2}$ covered by straw mulch with a rate of $0.5 \mathrm{~kg} \mathrm{~m}^{-2}$ in changing the time to runoff, runoff coefficient, sediment concentration and soil loss under laboratory conditions were considered by Sadeghi et al. (2015). The results of the study showed that the straw mulch had a more significant effect in reducing runoff coefficient, sediment concentration and soil loss at $0.25 \mathrm{~m}^{2}$ plot scale.

The effects of Manure on soil erosion have been studied by many researchers in recent decades. Mitchell and Gunther (1976) verified that the liquid manure provided a stabilizing effect on the soil surface, resulting in reduced rates of runoff and erosion. Giddens and Barnett (1980) revealed that the poultry litter could substantially reduce soil loss. Gilley and Eghball (1998) used beef cattle manure to control sediment transport and found that the manure could significantly reduce solids transport. Ginting et al. (1998) found that the application of beef manure could significantly reduce runoff and sediment. Gilley and Risse (2000) reported that the soil loss was influenced by the application of manure from 15 to $65 \%$ compared to non-manured sites. Gossin et al. (2003) showed that, although sediment concentrations were higher in the surface-applied treatments, the runoff volume was reduced and consequently declined the total sediment load. While Martínez et al. (2004) showed that the sediment concentration was higher in treated plots with cattle manure, Ramos and Martinez-Casanovas (2006) found that the sediment concentration in runoff was low in treated areas with cattle manure. The significant effect of poultry manure on soil loss reduction was also reported by Rees et al. (2011).

Some researchers studied the effects of polyacrylamide on sediment concentration and soil loss. Uysal et al. (1995) found that the polyacrylamide were quite effective for reducing soil loss. Yu et al. (2003), Shahbazi et al. (2004), Yonter (2010) and Lee et al. (2011) reported the positive effects of the polyacrylamide on soil loss, while Ai-Ping et al. (2011) found that the sediment concentration and soil loss increased significantly with the increasing polyacrylamide application rate. Tümsava and Kara (2011) revealed that the most effective rates of polyacrylamide on reducing soil losses rate were found to be 3.33 and $5 \mathrm{~kg} \mathrm{ha}^{-1}$.

The reviewed literature, verified variable behaviors and effectiveness of different mulches, which necessitated further studies under different conditions. However, no study has been conducted to comprehensively assess the effects of three organic and inorganic amendments on sediment concentration and soil loss under different rainfall intensities.

\section{Materials and methods}

\subsection{Soil characteristics}

A sandy-loam soil (14\% clay, $24 \%$ silt and $62 \%$ sand) was collected from the top layer of $0-20 \mathrm{~cm}$ (Kukal and Sarkar, 2010) of a summer rangeland in the Alborz Mountains, northern Iran, located at a latitude of $36^{\circ} 24^{\prime} 48.5^{\prime \prime}$, longitude of $51^{\circ} 44^{\prime} 59.4^{\prime \prime}$ and altitude of $1431 \mathrm{~m}$. The mean annual precipitation and temperature were about $587 \mathrm{~mm}$ and $11.3^{\circ} \mathrm{C}$, respectively. The bulk density, $\mathrm{pH}$, electrical conductivity and organic content of the study soil were measured as $1.376 \mathrm{~g} \mathrm{~cm}^{-3}, 7.95,75.5 \mu \mathrm{mohs} \mathrm{cm}^{-1}$ and $2.167 \%$, respectively. The collected soil was carried to the lab and air dried to optimum moisture content to maintain the relative stability of the soil aggregates (Kukal and Sarkar, 2011; Khaledi Darvishan et al., 2014; Moreno-Ramón et al., 2014; Brevik et al., 2015). The pebbles and plant residues were removed from the soil by passing it through a $8 \mathrm{~mm}$ sieve to obtain maximum similarity with the soil natural conditions (Defersha et al., 2011; Khaledi Darvishan et al., 2014; Ziadat et al., 2013).

Three layers of mineral pumice grains with different sizes and total thickness of $15 \mathrm{~cm}$ were used as a filter layer and placed at the bottom of the plots in order to simulate natural drainage condition and decreasing plot weight (Defersha et al., 2011; Khaledi Darvishan et al., 2014). A $15 \mathrm{~cm}$ thick soil layer was then placed on the top and separated from the mineral pumice by a sheet of porous jute (Defersha et al., 2011; Khaledi Darvishan et al., 2014). The soil was ultimately compacted by a PVC roller filled with cement to achieve the bulk density of $1.376 \mathrm{~g} \mathrm{~cm}^{-3}$ almost equal to that measured for the soil under natural conditions (Khaledi Darvishan et al., 2014). The moisture content of the soil was also set at some $29 \%$ similar to average amount reported for the real soil in the study area and during rainy season. The experiment's duration was about 10 to $15 \mathrm{~min}$, corresponding to climatological records for the selected rainfall intensities.

\subsection{Plot characteristics and rainfall simulation}

The laboratory experiments were conducted using three $6 \times 1 \mathrm{~m}$ erosion plots with a depth of $0.5 \mathrm{~m}$ and slope of $30 \%$, installed at the Faculty of Natural Resources of Tar- 
Table 1. Details on experimental setup and study treatments.

\begin{tabular}{llll}
\hline & Soil conservation treatment & \multicolumn{2}{l}{ Rainfall intensity treatment $\left(\mathrm{mm} \mathrm{h}^{-1}\right)$} \\
\hline Symbol & Specific treatment & Symbol level & Treatment level \\
\hline $\mathrm{C}$ & Control treatment & $I_{1}, I_{2}, I_{3}$ and $I_{4}$ & $30,50,70$ and 90 \\
\hline $\mathrm{T}$ & $\begin{array}{l}\text { Conservation treatment } \\
\text { with rice straw mulch, manure } \\
\text { and TA-200 polyacrylamide }\end{array}$ & $I_{1}, I_{2}, I_{3}$ and $I_{4}$ & $30,50,70$ and 90 \\
& & \\
\hline
\end{tabular}

biat Modares University, northern Iran. This slope is similar to that of the area where soil samples have been collected.

The rainfall simulator lab consisted of a $4000 \mathrm{~L}$ water tank and 27 pre-calibrated nozzles at three parallel lines with the ability to simulate average raindrops size of $1.3 \mathrm{~mm}$. The drops fell from a constant height of $4 \mathrm{~m}$, which ascertains the average terminal velocity of some $7.12 \mathrm{~m} \mathrm{~s}^{-1}$. The rainfall intensities of $30,50,70$ and $90 \mathrm{~mm} \mathrm{~h}^{-1}$ were then selected based on analysis made for the data collected from the nearest Kojour weather station $\left(36^{\circ} 13^{\prime} 48^{\prime \prime} \mathrm{NL}, 51^{\circ} 26^{\prime} 24^{\prime \prime} \mathrm{EL}\right.$ and $1550 \mathrm{~m}$ above mean sea level) with a return period of less than 20 years. The duration of each precipitation was set for all treatments as $10 \mathrm{~min}$ after commencement of runoff.

\subsection{Rice straw mulch, manure and TA-200 polyacrylamide treatments}

In the present study, rice straw mulch and manure were used as organic amendments and TA-200 polyacrylamide was applied to the plots as inorganic amendment. Each run was conducted using new soil and straw mulch (Adams, 1966; Liu et al., 2012), manure (Gilley and Eghball 1998) and polyacrylamide (Yu et al., 2003; Shahbazi et al., 2004; Tümsava and Kara, 2011). All amendments were spread on the soil surface 5 days before each experiment. For each plot, the rice straw mulch used with the surface cover, thickness and dry weight of about $90 \%$ (Adekalu et al., 2007; Kukal and Sarkar, 2010; Shi et al., 2013), $8 \mathrm{~cm}$ and $0.5 \mathrm{~kg} \mathrm{~m}^{-2}$, respectively. The manure with a cover of about $90 \%$ and dry weight of $0.3 \mathrm{~kg} \mathrm{~m}^{-2}$ (Ramos et al., 2006) was spread by hand (Ramos et al. 2006 and Garcia et al. 2008) at each plot. TA-200 polyacrylamide also was used with ground cover of about $5 \%$, sieve of 2 to $4 \mathrm{~mm}$ and rate of $50 \mathrm{~g} \mathrm{~m}^{-2}$. Two organic amendments of straw mulch and manure were used with the rates of 0.5 and $0.3 \mathrm{~kg} \mathrm{~m}^{-2}$, respectively, because of significant effects in water and soil conservation in previous studies (Ramos et al., 2006), while the rate of $50 \mathrm{~g} \mathrm{~m}^{-2}$ for TA-200 polyacrylamide was selected because of economic justification and minimal risk of detrimental effect to the environment. Each experiment was run with the new soil and the new amendment, i.e., rice straw, manure and TA-200 polyacrylamide. For each experiment, the top layer of soil were collected and replaced with new soil. The control treatment was then performed and corresponding variables, viz. runoff volume, sediment con- centration and soil loss were measured. Consequently, the study soil amendments were applied to the plots with eroded soil, and runoff volume, sediment concentration and soil loss were ultimately measured after 5 days and running artificial rainfalls. The use of 24 treatments in three replicates was formulated as a factorial design (Defersha and Melesse, 2012), as shown in Table 1.

A general view of the experimented plots is shown in Fig. 1. The control plots subjected to study rain storms were also monitored under identical lab conditions on bare soils and just before applying the straw mulch, manure and TA200 polyacrylamide to the same plots under consideration. Thus, the plots with eroded soils due to study rain storms were supposed as control conditions in order to assess the relative effectiveness of study amendments on controlling soil erosion.

\subsection{Runoff, suspended sediment concentration and soil loss measurements}

The runoff volume was measured at the outlet of each plot for the control (i.e., before mulching) and treated plots at intervals of $2 \mathrm{~min}$ (Ruiz-Sinoga et al., 2010) at intensities of 30, 50,70 and $90 \mathrm{~mm} \mathrm{~h}^{-1}$. The rainfall duration was prolonged 10 min after runoff commencement for all experimental treatments (Khaledi Darvishan et al., 2014). The sediment-laden runoff samples were taken from the total runoff (Khaledi Darvishan et al., 2014) at the outlet of the plots at the onset of receiving the first runoff drop with $10 \mathrm{~L}$ plastic buckets. The entire experiments were conducted for the similar treatments for rainfall intensities of $30,50,70$ and $90 \mathrm{~mm} \mathrm{~h}^{-1}$. The amounts of soil loss were then measured using decantation, oven drying at $105^{\circ} \mathrm{C}$ for $24 \mathrm{~h}$ and weighing techniques (Kukal and Sarkar, 2011; Gholami et al., 2013; Khaledi Darvishan et al., 2014). The concentrations of suspended material in runoff were consequently calculated based on the sediment mass and runoff volume data collected in each sample (Ai-Ping et al., 2011; Khaledi Darvishan et al., 2014).

\subsection{Statistical analysis}

The coefficient of determination was considered as a main index to select the best linear-on-nonlinear relationships between rainfall intensity and studied variables (average sed- 


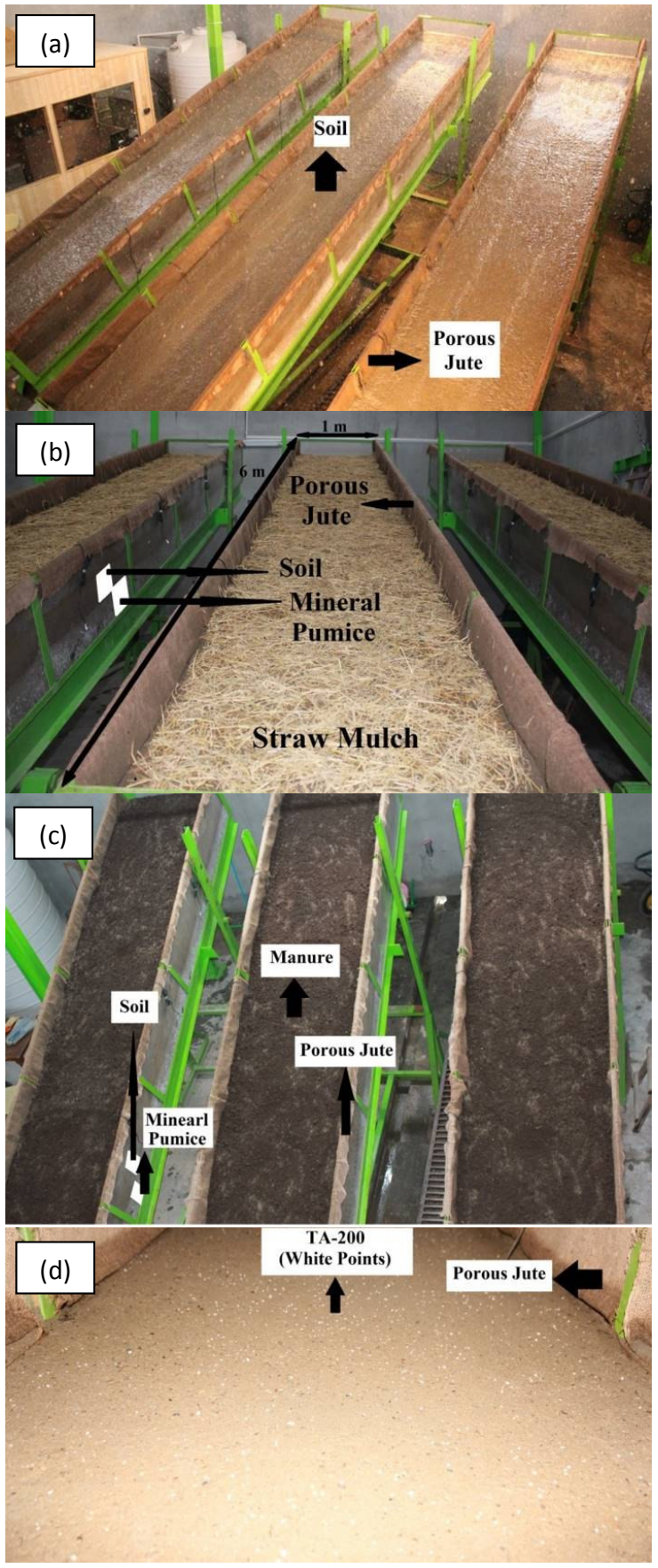

Figure 1. A view of untreated plots (a), treated plots with rice straw mulch (b), manure (c) and TA-200 polyacrylamide (d) under the lab condition.

iment concentration and soil loss). The same method was used to select the best relationships between soil conservation treatments and the studied variables.

To understand the statistical differences between studied variables in various levels of two studied factors (rainfall intensities or soil conservation treatments), one-way and twoway ANOVA were used in a general linear model (GLM) test in the SPSS 19 software package. Determination of homogeneous subgroups was then obtained for both studied factors with the help of Duncan test. All the differences with significant level less than 0.01 and 0.05 are statistically significant in confidence levels of 99 and $95 \%$, respectively.

\section{Results}

The runoff volume, sediment concentration and soil loss amounts before and after rice straw mulch, manure and TA200 polyacrylamide in each plot are shown in Table 2 . The relative effectiveness of straw mulch, manure and TA-200 polyacrylamide on sediment concentration and soil loss has ultimately been summarized in Table 3 . As shown in Table 3 , the strongest conservation effects on average sediment concentration and soil loss in all rainfall intensities were observed for straw mulch treatment, while the conservation effects of two other conservation treatments (manure and TA200 polyacrylamide) were relatively the same.

According to Table 3, it is observed that straw mulch has powerful conservation effects on average sediment concentration and soil loss compared to manure and TA-200 polyacrylamide. Figure 2 also shows the relationships between rainfall intensity and conservation treatments on average sediment concentration and soil loss.

The average sediment concentration and soil loss in at rainfall intensities of 30, 50, 70 and $90 \mathrm{~mm} \mathrm{~h}^{-1}$ (Table 2) showed that the straw mulch, manure and TA-200 polyacrylamide reduced sediment concentration and soil loss at all rainfall intensities.

Tables 4 and 5 show the GLM test and determination of significant differences between rainfall intensities and soil conservation treatments using post-hoc analysis (Duncan test). The results of the GLM test indicated that the effects of rainfall intensity, soil conservation and soil conservation $\times$ rainfall intensity on changing sediment concentration and soil loss was significant at a level of $99 \%$ (Table 4). The Duncan test showed that the subgroup of rainfall intensity was in four groups of $30,50,70$ and $90 \mathrm{~mm} \mathrm{~h}^{-1}$ (for sediment conservation and soil loss). The effect of TA-200 and manure on sediment concentration were similar and the effect of straw mulch on this variable was more and significantly different from two other soil conservation treatments and that was set in the first subgroup (Table 5).

\section{Discussion}

\subsection{Straw mulch}

The results (Table 2) showed that the straw mulch treatment essentially reduced soil loss and also sediment concentration (Mannering and Meyer, 1963; Adams, 1996; Adekalu et al., 2007; Groen and Woods, 2008; Smets et al., 2008; Jiang et al., 2011; Li et al., 2011; Gholami et al., 2013; Fernandez and Vega, 2014). This indicates that the flow could not get 
Table 2. Runoff volume, sediment concentration and soil loss from control and treated plots under different rainfall intensities.

\begin{tabular}{|c|c|c|c|c|c|c|c|c|}
\hline \multirow[t]{2}{*}{ Treatment } & \multirow[t]{2}{*}{ Plots } & \multirow[t]{2}{*}{$\begin{array}{c}\text { Rainfall } \\
\text { intensity }\left(\mathrm{mm} \mathrm{h}^{-1}\right)\end{array}$} & \multicolumn{2}{|c|}{ Runoff volume (L) } & \multicolumn{2}{|c|}{$\begin{array}{c}\text { Sediment } \\
\text { concentration }\left(\mathrm{g} \mathrm{L}^{-1}\right)\end{array}$} & \multicolumn{2}{|c|}{ Soil loss (g) } \\
\hline & & & Control & Treated & Control & Treated & Control & Treated \\
\hline \multirow[t]{14}{*}{ Rice straw mulch } & 1 & 30 & 21.06 & 19.04 & 7.07 & 3.98 & 146.55 & 72.64 \\
\hline & & 50 & 36.90 & 33.74 & 6.13 & 3.87 & 226.27 & 131.38 \\
\hline & & 70 & 58.82 & 51.05 & 9.36 & 5.83 & 551.87 & 290.89 \\
\hline & & 90 & 74.24 & 65.79 & 10.28 & 4.39 & 756.69 & 286.37 \\
\hline & 2 & 30 & 20.46 & 15.66 & 5.94 & 3.53 & 121.72 & 54.24 \\
\hline & & 50 & 35.95 & 35.05 & 7.43 & 3.69 & 266.64 & 128.94 \\
\hline & & 70 & 51.79 & 47.79 & 9.17 & 5.07 & 473.69 & 234.16 \\
\hline & & 90 & 74.05 & 70.65 & 10.71 & 4.47 & 787.94 & 315.10 \\
\hline & 3 & 30 & 19.08 & 16.32 & 6.78 & 3.97 & 128.17 & 54.87 \\
\hline & & 50 & 36.73 & 34.91 & 8.27 & 4.70 & 302.82 & 161.62 \\
\hline & & 70 & 51.18 & 49.17 & 8.79 & 5.92 & 449.45 & 281.53 \\
\hline & & 90 & 72.99 & 60.04 & 10.15 & 4.01 & 738.20 & 239.42 \\
\hline & Mean & & 46.10 & 41.60 & 8.34 & 4.45 & 412.50 & 187.60 \\
\hline & ndard & & 1.61 & 2.36 & 0.56 & 0.38 & 32.46 & 24.32 \\
\hline \multirow[t]{14}{*}{ Manure } & 1 & 30 & 19.69 & 21.9 & 6.21 & 6.10 & 120.59 & 127.66 \\
\hline & & 50 & 34.65 & 35.35 & 7.97 & 7.18 & 273.61 & 253.71 \\
\hline & & 70 & 56.98 & 56.84 & 8.70 & 7.83 & 492.64 & 444.52 \\
\hline & & 90 & 72.55 & 75.63 & 11.36 & 8.64 & 819.74 & 664.73 \\
\hline & 2 & 30 & 22.22 & 22.06 & 6.03 & 6.52 & 131.62 & 138.41 \\
\hline & & 50 & 33.50 & 31.51 & 7.34 & 6.56 & 245.78 & 204.98 \\
\hline & & 70 & 52.38 & 50.25 & 9.38 & 7.90 & 489.38 & 395.42 \\
\hline & & 90 & 75.78 & 73.53 & 11.47 & 10.35 & 870.08 & 779.40 \\
\hline & 3 & 30 & 21.53 & 18.34 & 5.73 & 4.80 & 121.07 & 83.54 \\
\hline & & 50 & 37.99 & 35.41 & 7.07 & 7.24 & 265.11 & 252.37 \\
\hline & & 70 & 50.43 & 53.23 & 9.09 & 8.17 & 452.26 & 435.99 \\
\hline & & 90 & 70.86 & 68.49 & 10.66 & 9.58 & 745.85 & 670.52 \\
\hline & Mean & & 45.71 & 45.21 & 8.42 & 7.57 & 418.98 & 370.94 \\
\hline & ndard & & 2.38 & 2.83 & 0.37 & 0.58 & 26.35 & 36.92 \\
\hline \multirow{12}{*}{$\begin{array}{l}\text { TA-200 } \\
\text { polyacrylamide }\end{array}$} & 1 & 30 & 20.77 & 20.18 & 5.75 & 6.66 & 117.62 & 139.44 \\
\hline & & 50 & 37.65 & 29.65 & 6.76 & 6.86 & 151.69 & 133.77 \\
\hline & & 70 & 58.75 & 50.42 & 6.49 & 4.81 & 120.34 & 84.67 \\
\hline & & 90 & 73.41 & 71.04 & 7.42 & 6.72 & 278.41 & 196.33 \\
\hline & 2 & 30 & 22.31 & 18.84 & 6.40 & 7.24 & 204.15 & 233.57 \\
\hline & & 50 & 32.04 & 32.40 & 7.31 & 6.06 & 257.81 & 183.43 \\
\hline & & 70 & 53.78 & 48.49 & 7.92 & 8.09 & 457.46 & 406.47 \\
\hline & & 90 & 68.94 & 70.07 & 9.09 & 7.89 & 485.41 & 381.49 \\
\hline & 3 & 30 & 18.69 & 16.48 & 7.70 & 7.74 & 405.37 & 391.63 \\
\hline & & 50 & 35.18 & 30.72 & 10.73 & 8.59 & 784.07 & 605.47 \\
\hline & & 70 & 52.71 & 50.55 & 9.88 & 8.77 & 673.30 & 614.65 \\
\hline & & 90 & 74.62 & 64.36 & 11.05 & 7.82 & 819.42 & 501.24 \\
\hline \multicolumn{3}{|c|}{ Mean } & 45.74 & 41.93 & 7.04 & 7.27 & 396.25 & 322.68 \\
\hline \multicolumn{3}{|c|}{ Standard error } & 2.71 & 2.01 & 0.61 & 0.60 & 43.53 & 32.93 \\
\hline
\end{tabular}


Table 3. Reduction rates in average sediment concentration and soil loss (\%) resulted from application of straw mulch, manure and TA-200 polyacrylamide and from various rainfall intensities.

\begin{tabular}{|c|c|c|c|c|c|}
\hline \multirow[t]{2}{*}{ Treatment } & \multirow[t]{2}{*}{ Variable } & \multicolumn{4}{|c|}{ Rainfall intensity $\left(\mathrm{mm} \mathrm{h}^{-1}\right)$} \\
\hline & & 30 & 50 & 70 & 90 \\
\hline Straw mulch & $\begin{array}{l}\text { Average sediment concentration }\left(\mathrm{g} \mathrm{L}^{-1}\right) \\
\text { Soil loss }(\mathrm{g})\end{array}$ & $\begin{array}{l}-41.91 \\
-54.36\end{array}$ & $\begin{array}{l}-43.47 \\
-46.74\end{array}$ & $\begin{array}{l}-38.31 \\
-45.07\end{array}$ & $\begin{array}{l}-58.69 \\
-63.24\end{array}$ \\
\hline Manure & $\begin{array}{l}\text { Average sediment concentration }\left(\mathrm{g} \mathrm{L}^{-1}\right) \\
\text { Soil loss }(\mathrm{g})\end{array}$ & $\begin{array}{l}-3.26 \\
-6.66\end{array}$ & $\begin{array}{l}-6.08 \\
-9.56\end{array}$ & $\begin{array}{l}-11.94 \\
-10.86\end{array}$ & $\begin{array}{l}-14.65 \\
-13.14\end{array}$ \\
\hline $\begin{array}{l}\text { TA-200 } \\
\text { polyacrylamide }\end{array}$ & $\begin{array}{l}\text { Average sediment concentration }\left(\mathrm{g} \mathrm{L}^{-1}\right) \\
\text { Soil loss }(\mathrm{g})\end{array}$ & $\begin{array}{l}-2.86 \\
-7.63\end{array}$ & $\begin{array}{l}-4.50 \\
-14.64\end{array}$ & $\begin{array}{l}-3.53 \\
-11.98\end{array}$ & $\begin{array}{l}-20.15 \\
-23.44\end{array}$ \\
\hline
\end{tabular}
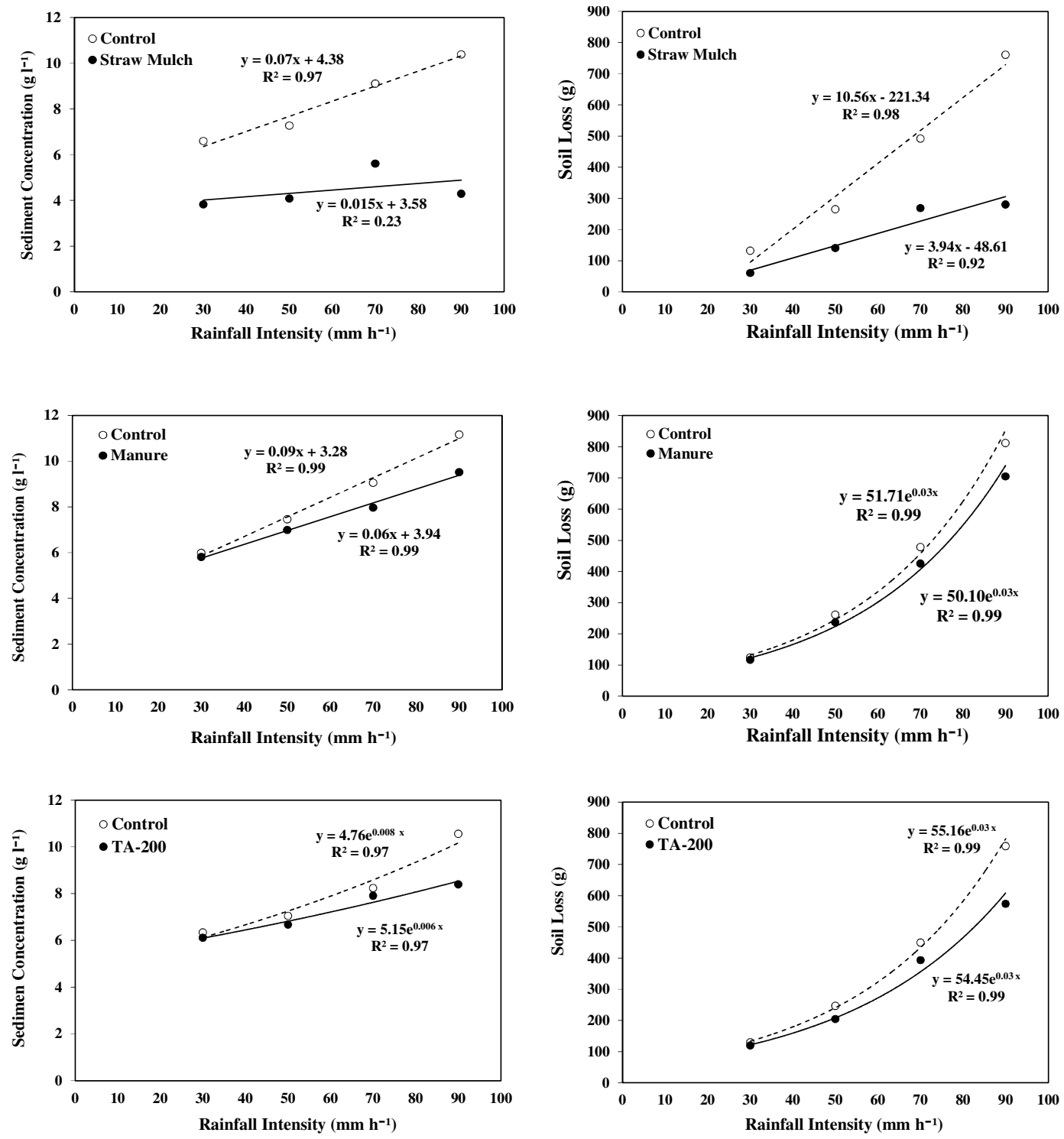

Figure 2. Relationships between rainfall intensity and organic and inorganic treatments on average sediment concentration (left column), soil loss (right column), rice straw mulch (top), manure (middle) and T-A 200 polyacrylamide (bottom). 
Table 4. GLM test for one-way and two-way ANOVA to calculate the effects of rainfall intensity and soil conservation treatments on sediment concentration and soil loss.

\begin{tabular}{clllll}
\hline Source & Dependent variables & $\mathrm{d} f$ & Mean square & $F$ value & $\begin{array}{l}\text { Significant } \\
\text { level }\end{array}$ \\
& & & & \\
\hline Rainfall intensity & $\begin{array}{l}\text { Sediment concentration }\left(\mathrm{g} \mathrm{L}^{-1}\right) \\
\text { Soil loss }(\mathrm{g})\end{array}$ & 3 & $\begin{array}{l}18.21 \\
529517.02\end{array}$ & $\begin{array}{l}65.50 \\
554.87\end{array}$ & $\begin{array}{l}0.00^{* *} \\
0.00^{* *}\end{array}$ \\
\hline \multirow{2}{*}{$\begin{array}{c}\text { Soil conservation } \\
\end{array}$} & Sediment concentration $\left(\mathrm{g} \mathrm{L}^{-1}\right)$ & 3 & 33.78 & 121.53 & $0.00^{* *}$ \\
& Soil loss $(\mathrm{g})$ & & 112278.653 & 117.66 & $0.00^{* *}$ \\
\hline $\begin{array}{c}\text { Rainfall intensity } \\
\times\end{array}$ & Sediment concentration $\left(\mathrm{g} \mathrm{L}^{-1}\right)$ & 9 & 6.62 & 1.84 & $0.00^{* *}$ \\
Soil conservation & Soil loss $(\mathrm{g})$ & & 22.91 & 21860.86 & $0.00^{* *}$ \\
\hline
\end{tabular}

** shows differences in significant level of 0.01 .

Table 5. Determination of significant differences between rainfall intensities and soil conservation treatments using post-hoc analysis (Duncan test).

\begin{tabular}{|c|c|c|c|c|}
\hline \multirow[t]{2}{*}{ Variable } & Subgroup 1 & Subgroup 2 & Subgroup 3 & Subgroup 4 \\
\hline & \multicolumn{4}{|c|}{ Subgroups for rainfall intensity } \\
\hline Sediment concentration $\left(\mathrm{g} \mathrm{L}^{-1}\right)$ & 30 & 50 & 70 & 90 \\
\hline \multirow[t]{2}{*}{ Soil loss $(\mathrm{g})$} & 30 & 50 & 70 & 90 \\
\hline & \multicolumn{4}{|c|}{ Subgroups for soil conservation } \\
\hline Sediment concentration $\left(\mathrm{g} \mathrm{L}^{-1}\right)$ & $\begin{array}{l}\text { Straw mulch }) \\
(4.45)\end{array}$ & $\begin{array}{l}\text { TA-200 and manure } \\
(7.27 \text { and } 7.57)\end{array}$ & $\begin{array}{l}\text { Control } \\
(8.27)\end{array}$ & - \\
\hline Soil loss (g) & $\begin{array}{l}\text { Straw mulch } \\
(187.60)\end{array}$ & $\begin{array}{l}\text { TA-200 } \\
(322.68)\end{array}$ & $\begin{array}{l}\text { Manure } \\
(370.94)\end{array}$ & $\begin{array}{l}\text { Control } \\
(409.24)\end{array}$ \\
\hline
\end{tabular}

Figures given in brackets show mean values.

enough power to detach particles (Poesen and Lavee, 1991) with an amount of $0.5 \mathrm{~kg} \mathrm{~m}^{-2}$ because the depth of the mulch trapped detaching soil aggregates. The straw mulch could decrease runoff energy for particle detachment and transport (Mannering and Meyer, 1963). The effective relationship between average sediment concentration and rainfall intensity in the control and treated plots was linear-direct (Fig. 2). The effective relationship between sediment yield and rainfall intensity in both treatments was also linear-direct (Fig. 2). The effective role of stubble mulch has been reported by Smets et al. (2008). The results also verified the maximum effectiveness of straw mulch on sediment concentration and soil loss at the rainfall intensity of $90 \mathrm{~mm} \mathrm{~h}^{-1}$ with rates of -58.69 and $-63.23 \%$, respectively (Table 3 ). They had minimum effects at the rainfall intensities of 70 (straw mulch) and $30 \mathrm{~mm} \mathrm{~h}^{-1}$ (manure and TA-200 polyacrylamide). Soil loss was reduced because runoff and rainfall detachment were diminished and soil infiltration rates were increased (Jordan et al., 2010). This effect is larger for the high-intensity than for the medium-intensity rainfall as reported by Fox and Bryan (1999) and Assouline and Ben-Hur (2006).

\subsection{Manure mulch}

The results of Table 2 showed that the manure could reduce sediment concentration for all rainfall intensities. Scrutinizing results (Table 2) showed that the manure treatment essentially reduced sediment concentration and soil loss (Mitchell and Gunther, 1976; Giddens and Barnett, 1980; Gilley and Eghball, 1998; Ramos; Gilley and Risse, 2000; MartinezCasanovas, 2006 and Rees et al., 2011). The manure could also reduce soil loss because runoff amount and rainfall detachment were diminished and soil infiltration rates increased. Gossin et al. (2003) showed that the application of manure could reduce the total sediment load through decreasing runoff volume. Gessel et al. (2004) also showed that the application of manure in plot scale could decrease soil loss compared to the non-manured plot. Martínez et al. (2004) showed that the manure was effective on sediment conservation at rainfall intensity of $80 \mathrm{~mm} \mathrm{~h}^{-1}$. This disagreed with Mooers et al. (1948) who showed that the manure had less impact in soil conservation. The relationships between sediment concentration and soil loss with rainfall intensity in control and treated plots with manure were en- 
tirely significant with $R^{2}=0.99(p \leq 0.01)$ and linear-direct and exponential-direct, respectively (Fig. 2).

\subsection{TA-200 polyacrylamide amendment}

Table 2 showed that the TA-200 polyacrylamide decreased soil loss and sediment concentration (Uysal et al., 1995; Shahbazi et al., 2004; Tang et al. 2006; Ai-Ping et al., 2011; Lee et al., 2011) at a rate of $50 \mathrm{~g} \mathrm{~m}^{-2}$. The relationships between rainfall intensity with sediment concentration and soil loss were exponential with respective coefficients of determination of 0.97 and 0.99 for untreated and treated plots (Table 2). This amendment had more effect at rainfall intensity of $90 \mathrm{~mm} \mathrm{~h}^{-1}$ than for sediment concentration and soil loss at rates of -20.15 and $-23.44 \%$, respectively (Table 3 ). Sojka et al. (1998) and Sepaskhah and Bazrafshan-Jahromi (2006) showed that the polyacrylamide had more effect on soil loss control for low rainfall intensity.

\subsection{Cross comparison of study treatments performance}

\subsubsection{Runoff}

The result comparison showed that the straw mulch was effective in reducing runoff toward two other amendments (Smets et al., 2008; Shi et al., 2013). This amendment could be more effective at rainfall intensity of $30 \mathrm{~mm} \mathrm{~h}^{-1}$. However, the TA-200 polyacrylamide had less impact on runoff changes compared to those for straw mulch and manure (Prats et al., 2014). The runoff volume decreased because straw mulch pieces (Duley and Kelly, 1939; Liu et al., 2012), manure (Ginting et al., 1998; Rasoulzadeh and Yaghoubi, 2010) and TA-200 (Uysal et al., 1995; Yu et al., 2003; Tang et al. 2006; Pajuohesh et al. 2008) could store more runoff. However, the greater depth of the straw mulch increased protection of the immediate soil surface with absorption of water and holding excess surface water on the soil surface by mechanical impedance (Adams, 1966; Khan et al., 1988).

\subsubsection{Sediment concentration and soil loss}

The straw mulch, manure and TA-200 polyacrylamide could also decrease sediment concentration and soil loss in rainfall intensities of $30,50,70$ and $90 \mathrm{~mm} \mathrm{~h}^{-1}$. All study treatments could reduce sediment concentration and soil loss at rainfall intensity of $90 \mathrm{~mm} \mathrm{~h}^{-1}$ more than other intensities. This means that the significant declines in soil loss should be attributed to the organic and inorganic recovery of the plots rather than to variations of the rainfall intensities. The measured soil loss for straw mulch, manure and TA-200 polyacrylamide were $412.50,418.98$ and 396.25 for the control plots and 187.60, 370.94 and 322.68 for the conserved plots (Table 2). Similar results have been reported by Wagenbrenner et al. (2006).

García-Orenes et al. (2010) and Prats et al. (2014) showed that the straw mulch was effective on soil loss control. It might be because of the low rate of the soil clay (almost $14 \%$ ) which could not facilitate better performance of TA200. Yonter (2010) and Tümsava and Kara (2011) stated that the polyacrylamide had an effective role on soil loss in soils with clay $>30 \%$. However, some previous studies (e.g., Fox and Bryan, 1999; Assouline and Ben-Hur, 2006) indicated that the effect of slope on soil loss was dependent on rainfall intensity. This effect is larger for the high-intensity rainfall than for the medium-intensity rainfall. Results showed that the straw mulch had more appropriate and better effect on sediment concentration and soil loss control. Smets et al. (2008) agreed that the straw mulch had an effective role on soil loss control. The better effect of straw mulch was due to greater coverage (Gholami et al., 2013; Shi et al., 2013; Fernandez and Vega, 2014), physical role of straw pieces as a resistant barriers against detachment (Mannering and Meyer, 1963; Poesen and Lavee, 1991), reducing runoff amount and speed and also increasing infiltration (Jordan et al., 2010).

The one-way ANOVA results (Table 4) showed that the sediment concentration and soil loss increases with increasing rainfall intensity of both the control and the soil conservation treatments and the effect of rainfall intensity were significant on study variables $\left(R^{2}=0.99\right)$. However, the conservation treatments reduced sediment concentration and soil loss and this effect was significant on study variables $\left(R^{2}=0.99\right)$.

Determination of significant differences between rainfall intensities and soil conservation treatments using post-hoc analysis (Table 5) showed that the rainfall intensities of 30 , 50,70 and $90 \mathrm{~mm} \mathrm{~h}^{-1}$ were classified in four different subgroups. The treatments in regards to sediment concentration were classified in three subgroups of straw mulch, TA-200, manure and control. The amounts of TA-200 and manure were close to control treatment, while for soil loss the soil conservation treatments grouped were in four different subgroups. They were separated into straw mulch, TA-200, manure and control, but the straw mulch had significant differences with two other soil conservation treatments.

\section{Conclusions}

The present study focused on the effects of straw mulching, manure and TA-200 polyacrylamide application on sediment concentration and soil loss control under different rainfall intensities under laboratory conditions at a medium-sized plot scale. It can be concluded from the results that the straw mulching, manure and TA-200 polyacrylamide at respective rates of 500,300 and $50 \mathrm{~g} \mathrm{~m}^{-2}$ and $6 \mathrm{~m}^{2}$ plots with $30 \%$ slope could significantly decrease the sediment concentration and soil loss with different rates. The straw mulch, manure and TA-200 polyacrylamide could reduce sediment concentration and soil loss at rainfall intensity of $90 \mathrm{~mm} \mathrm{~h}^{-1}$ more than other study intensities. However, further detailed studies with different levels of straw mulches, manures, polyacrylamide and slopes and even under different conditions are needed to allow us to draw comprehensive conclusions. 
Acknowledgements. This project was funded by the Faculty of Natural Resources at Tarbiat Modares University of Iran. Authors also thank the laboratory assistants and other post-graduate students for their help in running experiments and collecting data.

Edited by: P. Pereira

\section{References}

Adams, J. E.: Influence of mulches on runoff, erosion and moisture depletion, Soil Sci. Soc. Am. J., 30, 110-114, 1966.

Adekalu, K. O., Olorunfemi, I. A., and Osunbitan, J. A.: Grass mulching effect on infiltration, surface runoff and soil loss of three agricultural soils in Nigeria, Bioresource Technol., 98, 912-917, 2007.

Ai-Ping, W., Fa-Hu, L., and Sheng-Min, Y.: Effect of polyacrylamide application on runoff, erosion and soil nutrient loss under simulated rainfall, Pedosphere, 21, 628-638, 2011.

Assoulin, S. and Ben-Hur, M.: Effects of rainfall intensity and slope gradient on the dynamics of interrill erosion during soil surface sealing, Catena, 66, 211-220, 2006.

Brevik, E. C., Cerdá, A., Mataix-Solera, J., Pereg, L., Quinton, J. N., Six, J., and Van Oost, K.: The interdisciplinary nature of SOIL, SOIL, 1, 117-129, doi:10.5194/soil-1-117-2015, 2015.

Cerdà, A.: Effect of climate on surface flow along a climatological gradient in Israel. A field rainfall simulation approach, J. Arid Environ., 38, 145-159, 1998.

Cerdà, A.: Effects of rock fragment cover on soil infiltration, interrill runoff and erosion, Eur. J. Soil Sci., 52, 59-68, 2001.

Cerdà, A., Flanagan, D. C., le Bissonnais, Y., and Boardman, J.: Soil erosion and agriculture, Soil Till. Res., 106, 107-108, 2009a.

Cerdà, A., Giménez-Morera, A., and Bodí, M. B.: Soil and water losses from new citrus orchards growing on sloped soils in the western Mediterranean basin, Earth Surf. Proc. Land., 34, 1822 1830, 2009b.

Cerdà, A., Brazier, R., Nearing, M., and de Vente, J.: Scales and erosion, Catena, 102, 1-2, 2013.

Defersha, M. B. and Mellese, A. M.: Effect of rainfall intensity, slope and antecedent moisture content on sediment concentration and sediment enrichment ratio, Catena, 90, 47-52, 2012.

Defersha, M. B., Quraishi, S., and Melesse, A.: The effect of slope steepness and antecedent moisture content on interrill erosion, runoff and sediment size distribution in the highlands of Ethiopia, Hydrol. Earth Syst. Sci., 15, 2367-2375, doi:10.5194/hess-152367-2011, 2011.

Duley, F. L. and Kelly, L. L.: Effect of soil type, slope and surface conditions on intake of water, Nebraska Agr. Exp. Station Research Bulletin, 112, 16 pp., 1939.

Fernández, C. and Vega, J. A.: Efficacy of bark strands and straw mulching after wildfire in NW Spain: Effects on erosion control and vegetation recovery, Ecol. Eng., 63, 50-57, 2014.

Fernández, C., Vega, J. A., Jiménez, E., Vieira, D. C. S., Merino, A., Ferreiro, A., and Fonturbel, T.: Seeding and mulching + seeding effects on post-fire runoff, soil erosion and species diversity in Galicia (NW Spain). Land Degrad. Dev., 23, 150-156, 2012.

Fox, D. M. and Bryan, R. B.: The relationship of soil loss by interrill erosion to slope gradient, Catena, 38, 211-222, 1999.
Gabarrón-Galeote, M. A., Martínez-Murillo, J. F., Quesada, M. A., and Ruiz-Sinoga, J. D.: Seasonal changes in the soil hydrological and erosive response depending on aspect, vegetation type and soil water repellency in different Mediterranean microenvironments, Solid Earth, 4, 497-509, doi:10.5194/se-4-497-2013, 2013.

Garcia, A. M., Veith, T. L., Kleinman, P. J. A., Rotz, C. A., and Saporito, L. S.: Assessing manure management strategies through small-plot research and wholefarm modeling, J. Soil Water Conserv., 63, 204-211, 2008.

García-Orenes, F., Guerrero, C., Roldán, A., Mataix-Solera, J., Cerdà, A., Campoy, M., Zornoza, R., Bárcenas, G., and Caravaca, F.: Soil microbial biomass and activity under different agricultural management systems in a semiarid Mediterranean agroecosystem, Soil Till. Res., 109, 110-115, 2010.

Gessel, P. D., Hansen, N. C., Moncrief, J. F., and Schmitt, M. A. Rate of fall-applied liquid swine manure: effects on runoff transport of sediment and phosphorus, J. Environ. Qual., 33, 18391844, 2004.

Gholami, L., Sadeghi, S. H. R., and Homaee, M.: Straw mulching effect on splash erosion, runoff and sediment yield from eroded plots. Soil Sci. Soc. Am. J., 77, 268-278, 2013.

Giddens, J. and Barnett, A. P.: Soil loss and microbiological quality of runoff from land treated with poultry litter, J. Environ. Qual., 9, 518-520, 1980.

Gilley, J. E. and Eghball, B.: Runoff and erosion following field application of beef cattle manure and compost, T. Am. Soc. Agr. Eng., 41, 1289-1294, 1998.

Gilley, J. E. and Risse, L. M.: Runoff and soil loss as affected by the application of manure, T. Am. Soc. Agr. Eng., 43, 1583-1588, 2000.

Gilley, J. E., Finkner, S. C., and Varvel, G. E.: Runoff and erosion as affected by sorghum and soybean residue, T. Am. Soc. Agr. Eng., 29, 1605-1610, 1986.

Ginting, D., Moncrief, J. F., Gupta, S. C., and Evans, S. D. Corn yield, runoff and sediment losses from manure and tillage systems, J. Environ. Qual. 27, 1396-1402, 1998.

Gossin, C., Teichmeier, G. J., Erickson, G. E., Klopfenstein, T. J., and Walters, D. T.: Impact of manure application on phosphorus in surface runoff and soil erosion, Nebraska Beef Cattle Reports 2003, 228, 51-54, 2003.

Groen, A. H. and Woods, S. W.: Effectiveness of aerial seeding and straw mulch for reducing post-wildfire erosion, North-Western Montana, USA, Int. J. Wildland Fire, 17, 559-571, 2008.

Huang, J., Wang, J., Zhao, X., Li, H., Jing, Z., Gao, X., Chen, X., and $\mathrm{Wu}$, P.: Simulation study of the impact of permanent groundcover on soil and water changes in Jujube orchards on sloping ground, Land Degrad. Dev., doi:10.1002/ldr.2281, 2014.

Jiang, L., Dami, I., Mathers, H. M., Dick, W. A., and Doohan, D. The effect of straw mulch on simulated simazine leaching and runoff, Weed Sci., 59, 580-586, 2011.

Jiménez, M. N., Fernández-Ondoño, E., Ripoll, M. A., CastroRodríguez, J., Huntsinger, L., and Navarro, F. B.: Stones and organic mulches improve the Quercus Ilex L. Afforestation success under mediterranean climatic conditions, Land Degrad. Dev, doi:10.1002/ldr.2250, 2013.

Jordán, A., Zavala, L. M., and Gil, J.: Effects of mulching on soil physical properties and runoff under semi-arid conditions in southern Spain, Catena, 81, 77-85, 2010. 
Karami, A., Homaee, M., Afzalinia, S., Ruhipour, H., and Basirat, S.: Organic resource management: Impacts on soil aggregate stability and other soil physico-chemical properties, Agr. Ecosyst. Environ., 148, 22-28, 2012.

Khaledi Darvishan, A. V., Sadeghi, S. H. R. Homaee, M., and Arabkhedri, M.: Measuring sheet erosion using synthetic colorcontrast aggregates, Hydrol. Process., 28, 4463-4471, 2014.

Khan, M. J., Monke, E. J., and Foster, G. R.: Mulch cover and canopy effect on soil loss, T. Am. Soc. Agr. Eng., 31, 706-711, 1988.

Kukal, S. S. and Sarkar, M.: Splash erosion and infiltration in relation to mulching and polyviny alcohol application in semi-arid tropics, Arch. Agronomy Soil Sci., 56, 697-705, 2010.

Kukal, S. S. and Sarkar, M.: Laboratory simulation studies on splash erosion and crusting in relation to surface roughness and raindrop size, J. Indian Soci. Soil Sci., 59, 87-93, 2011.

Lee, S. S., Gantzer, C. J., Thompson, A. L., and Anderson, S. H.: polyacrylamide efficacy for reducing soil erosion and runoff as influenced by slope, J. Soil Water Conserv., 66, 172-177, 2011.

Li, X. H., Zhang, Z. Y., Yang, J., Zhang, G. H, and Wang, B.: Effects of Bahia grass cover and mulch on runoff and sediment yield of sloping red soil in southern China, Pedosphere, 21, 238-243, 2011.

Liu, Y., Taoa, Y., Wana, K. Y., Zhanga, G. S., Liub, D. B., Xiongb, G. Y., and Chena, F.: Runoff and nutrient losses in citrus orchards on sloping land subjected to different surface mulching practices in the danjiangkou reservoir area of China, Agr. Water Manage., 110, 34-40, 2012.

Mandal, D. and Sharda, V. N.: Appraisal of soil erosion risk in the Eastern Himalayan region of India for soil conservation planning, Land Degrad. Dev., 24, 430-437. 2013.

Mannering, J. V. and Meye, D.: Effects of various rates of surface mulch on infiltration and erosion, Soil Sci. Soc. Am. J., 27, 8486, 1963.

Martínez, I. A., Ramos, M. C., and Martínez-Casanovas, J. A.: Effects of composted cattle manure on erosion rates and nutrient losses, EUROSOIL, Publication on CD-ROM, Session 12: Soil Erosion, 8 pp., 2004.

Mitchell, J. K. and Gunther, R. W.: The effects of manure applications on runoff, erosion and nitrate losses, T. Am. Soc. Agr. Eng. 19, 1104-1106, 1976.

Mooers, C. A., Washko, J. B., and Young, J. B.: Effects of wheat straw, lespedeza sericea hay and farmyard manure as soil mulches, on the conservation of moisture and the production of nitrates, Soil Sci., 66, 307-316, 1948.

Moreno-Ramón, H., Quizembe, S. J., and Ibáñez-Asensio, S.: Coffee husk mulch on soil erosion and runoff: experiences under rainfall simulation experiment, Solid Earth, 5, 851-862, doi:10.5194/se-5-851-2014, 2014.

Morgan, R. P. C.: Soil Erosion and Conservation, Longman Scientific and Technical, Burnt Mile, Harlow, UK, 304, 1986.

Pajuohesh, M., Refahi, H. G., Zehtabian, G. R., Salehpour Jam, A., and Kianian, M. K.: Effects of various super absorbent concentrations on runoff volume in slopes and various intensity of simulated rainfall in Shahrekord plain, Desert, 12, 121-128, 2008.

Poesen, J. W. A. and Lavee, H.: Effects of size and incorporation of synthetic mulch on runoff and sediment yield from interrills in a laboratory study with simulated rainfall, Soil Till. Res., 21, 209-223, 1991.
Prats, S. A., Martins, M. A., Malvar, M. C., Ben-Hur, M., and Keizer, J. J.: Polyacrylamide application versus forest residue mulching for reducing post-fire runoff and soil erosion, Sci. Total Environ., 468-469, 464-474, 2014.

Ramos, M. C. and Martínez-Casasnovas, J. A.: Erosion rates and nutrient losses affected by composted cattle manure application in vineyard soils of NE Spain, Catena, 68, 177-185, 2006.

Rasoulzadeh, A. and Yaghoubi, A.: Effect of cattle manure on soil physical properties on a sandy clay loam soil in North-West Iran, J. Food Agric. Environ., 8, 976-979, 2010.

Rees, H. W., Chow, T. L., Zebarth, B. J., Xing, Z., Toner, P., Lavoie, J., and Daigle, J. L.: Effects of supplemental poultry manure applications on soil erosion and runoff water quality from a loam soil under potato production in north-western New Brunswick, J. Soil Sci., 91, 595-613, 2011.

Ruiz-Sinoga, J. D., Romero-Diaz, A., Ferre-Bueno, E., and Martínez-Murillo, J. F.: The role of soil surface conditions in regulating runoff and erosion processes on a metamorphic hillslope (southern Spain) soil surface conditions, runoff and erosion in southern Spain, Catena, 80, 131-139, 2010.

Sadeghi, S. H. R., Gholami, L., Sharifi, E., Khaledi Darvishan, A., and Homaee, M.: Scale effect on runoff and soil loss control using rice straw mulch under laboratory conditions, Solid Earth, 6, 1-8, doi:10.5194/se-6-1-2015, 2015.

Sepaskhah, A. R. and Bazrafshan-Jahromi, A. R.: Controlling runoff and erosion in sloping land with polyacrylamide under a rainfall simulator, Biosyst. Eng., 93, 469-474, 2006.

Shahbazi, A., Sarmadian, F., Refahi, H. G. H., and Gorji, M.: The effect of polyacrylamide on erosion and runoff in salt soils, Iran Agriculture Journal 36, 1103-1112, 2004. (In Persian).

Shi, Z. H., Yue, B. J., Wang, L., Fang, N. F., Wang, D., and Wu, F. Z.: Effects of mulch cover rate on interrill erosion processes and the size selectivity of eroded sediment on steep slopes, Soil Sci. Soc. Am. J., 77, 257-267, 2013.

Smets, T., Poesen, J., and Bochet, E.: Impact of plot length on the effectiveness of different soil-surface covers in reducing runoff and soil loss by water, Prog. Phys. Geog., 32, 654-677, 2008.

Sojka, R. E., Lentz, R. D., Trout, T. J., Ross, C. W., Bjorneberg, D. L., and Aase, J. K.: Polyacrylamide effects on infiltration in irrigated agriculture, J. Soil Water Conserv., 53, 325-331, 1998.

Tang, Z., Lei, T., Yu, J., Shainberg, I., Mamedov, A. I., Ben-Hur, M., and Levy, G. J.: Runoff and interrill erosion in sodic soils treated with dry PAM and phosphogypsum, Soil Sci. Soc. Am. J., 70, 679-690, 2006.

Tümsava, Z. and Kara, A.: The Effect of Polyacrylamide (PAM) applications on infiltration, runoff and soil losses under simulated rainfall conditions, Afr. J. Biotechnol., 10, 2894-2903, 2011.

Uysal, H., Taysun, A., and Kose, C.: Toprak özellikleriyle birlikte kümelepmeyi saðlayan bazý polimerlerin laboratuvar kopullarý altýnda su erozyonu üzerine etkileri, edited by: Mansuz, N., Unver, I., and Cayci, G., Ýlhan Akalan Toprak ve Çevre Sempozyumu, 7 Kasým 1995, Ankara, Turkey, 101-111, 1995 (in Turkish).

Wagenbrenner, J. W., MacDonald, L. H., and Rough, D.: Effectiveness of three post-fire rehabilitation treatments in the Colorado Front Range, Hydrol. Process., 20, 2989-3006, 2006.

Wolancho, L. W.: Watershed management: an option to station dam and reservoir function in Ethiopia, Environ. Sci. Technol., 5, 262-273, 2010. 
Yonter, G.: Effects of polyvinylalcohol (PVA) and polyacrylamide (PAM) as soil conditioners on erosion by runoff and by splash under laboratory conditions, Ekoloji, 19, 35-41, 2010.

Yu, J., Lei, T., Shainberg, I., Mamedor, A. I., and Levy, G. J.: Infiltration and erosion in soils treated with dry PAM and gypsum, Soil Sci. Soc. Am. J. 67, 630-636, 2003.

Xu, Q. X., Wang, T. W., Cai, C. F., Li, Z. X., and Shi, Z. H.: Effects of soil conservation on soil properties of citrus orchards in the Three-Gorges Area, China, Land Degrad. Dev., 23, 34-42, 2012.
Zhao, G., Mu, X., Wen, Z., Wang, F., and Gao, P.: Soil erosion, conservation, and Eco-environment changes in the Loess Plateau of China, Land Degrad. Dev., 24, 499-510, 2013.

Ziadat, F. M. and Taimeh, A. Y.: Effect of rainfall intensity, slope and land use and antecedent soil moisture on soil erosion in an arid environment, Land Degrad. Dev., 24, 582-590, 2013. 